$$
\begin{aligned}
& \text { SB436 } \\
& 16 \\
& 1909
\end{aligned}
$$





\section{SB 436}

. N6

\section{9}

Copy 1

A Four-fold Word for Trees

By CARL BANNWART, Secretary

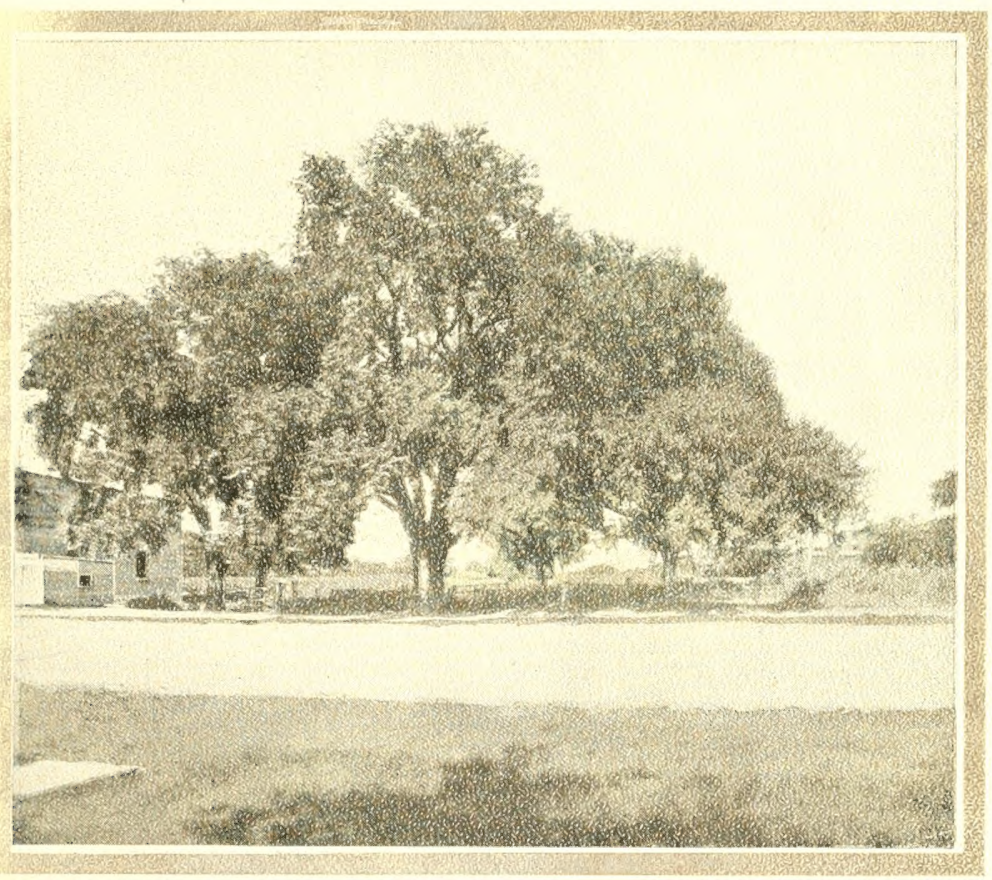

BELLEVILLE ELM

NEWARK SHADE TREE COMMISSION 


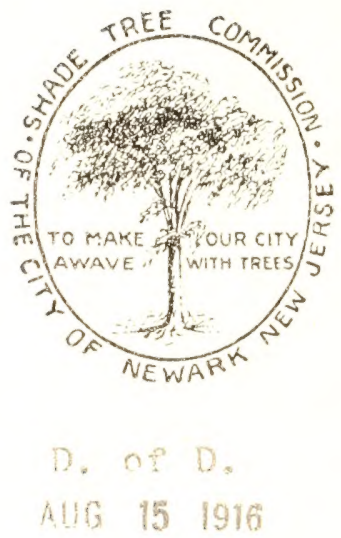




\section{A Four-fold Word for Trees}

In this day of resthetic awakening, much is Beauty being done to bring about the "City Beautiful." The important cities are all in the procession. Park and Art Commissions, Architects' and Artists' Societies vie with each other in efforts to achieve

Trees Indispen 5able civic development. It is encouraging to the planter of trees to note that all such organizations declare trees to be indispensable elements in the construction of the city beautiful. Trees supply a two-fold beanty. Beauty of form and beauty of color. Graceful in outline and decked in Nature's green, they have a double attraction. Whether singly, or in mass, there is nothing in a city's streets so charming as bright green trees.

The French hold the "Grand Prix" as the creators of the paris most beautiful city-Paris. It is declared that the trees of Paris with their stately, growing columns, their overarching. living, moving, rustling canopies of green are nore potent elements of the city's beanty than the Grecian pillars of the Madeline, or the marble facades of the "Hotel de Ville." But we have a conspicuous example of civic art in our own country, viz: Washington, the nation's capital. Here washington again, trees are a prominent featno. 'Their background of green enhances the beauty of every statue, and frames 


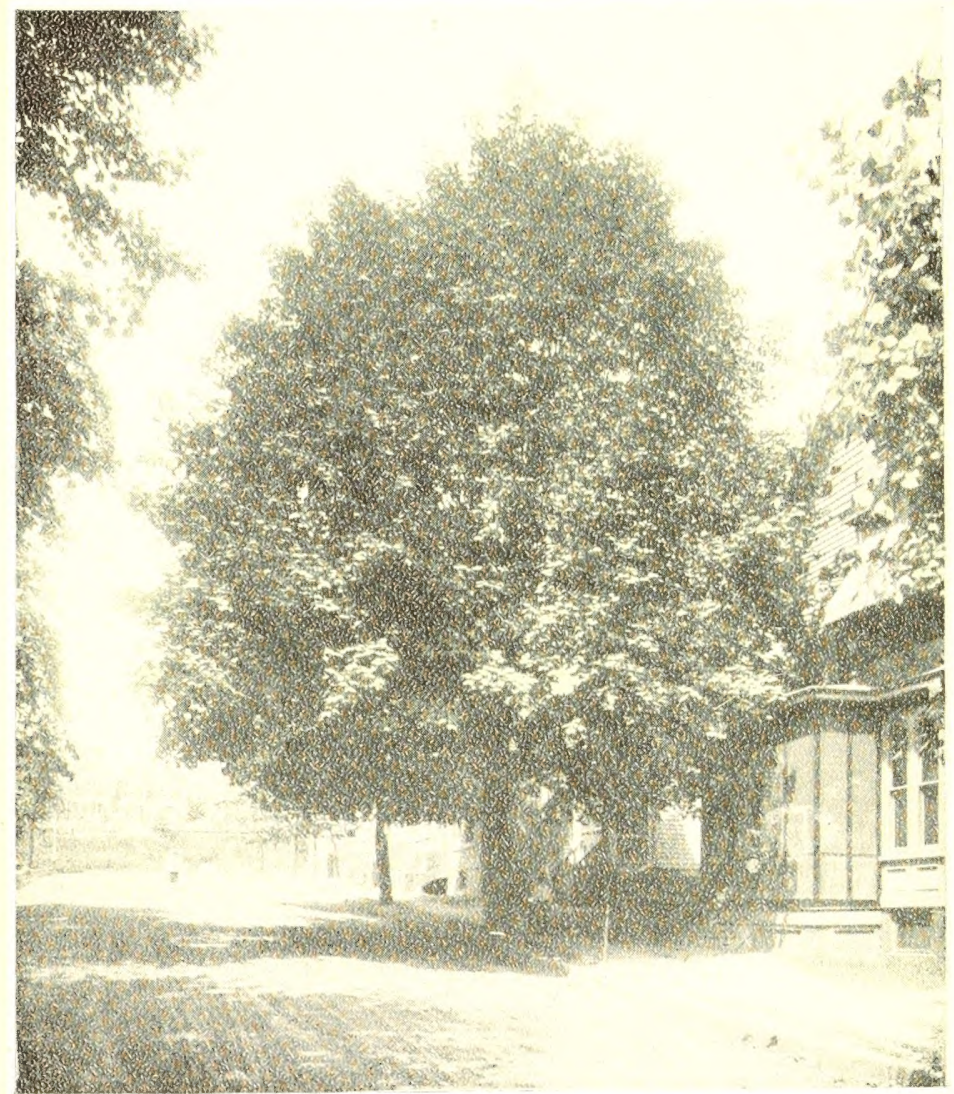

NORWAY MAPLE, PIONIER STREET

every great building. The lines of well-planted, well-kept trees wind co-extensive with the bontevards and by their variety and beauty elicit the admiration of all beholders.

Newark Civic patriotism and the desire to excel are already at work bringing about in Newark the city beautiful. These 
sentiments have been finding expression, for instance, in splendid municipal and business edifices. All right-minded men recognize the importance of beautiful public and private buildings. Yet all will agree, we think, that the touch of nature too is needed and is even more important. Indeed. it is the universal judgment that the attractiveness of a city depends largely on the trees planted along its streets. Whether one regards the graceful outlines of the leafless trunks and limbs, the tiny bud hastening its preparation for Spring, the feathery foliage as Spring bursts out anew, the glory of Summer, or the splendor of autumnal colors when every leaf becomes a flower, the tree stands forth a miracle of beanty and of power. If one healthy tree is a source of pleasure to the observant, long rows of well-kept trees with their graceful arches and nodding plumes, their grateful shade and flecks of sunshine, command attention from the most careless. They add more, we believe, to the beauty of a street than elaborate architecture-giving a loveliness and grace otherwise unattainable. Thus the street of the poor man may rival that of the rich.

Trees, because of their beauty, perpetually yield pure pleasure to the people: and this more and more as the people awake to them. Whatever thus adds to the stock of human joys has a real usefulness. That an American city should not be outdone by foreign cities in availing itself of this source of contentment seems beyond question. As President Eliot puts it: "The final aim of government by the people for the people is to increase the satisfaction and the joys of life to the highest possible degree for the greatest number of persons - to increase, that is, the number, variety and intensity of those sensations and emotions which give innocent and frequently recurring pleasure." And that is precisely the kind of pleasure given by trees, a pleasure 


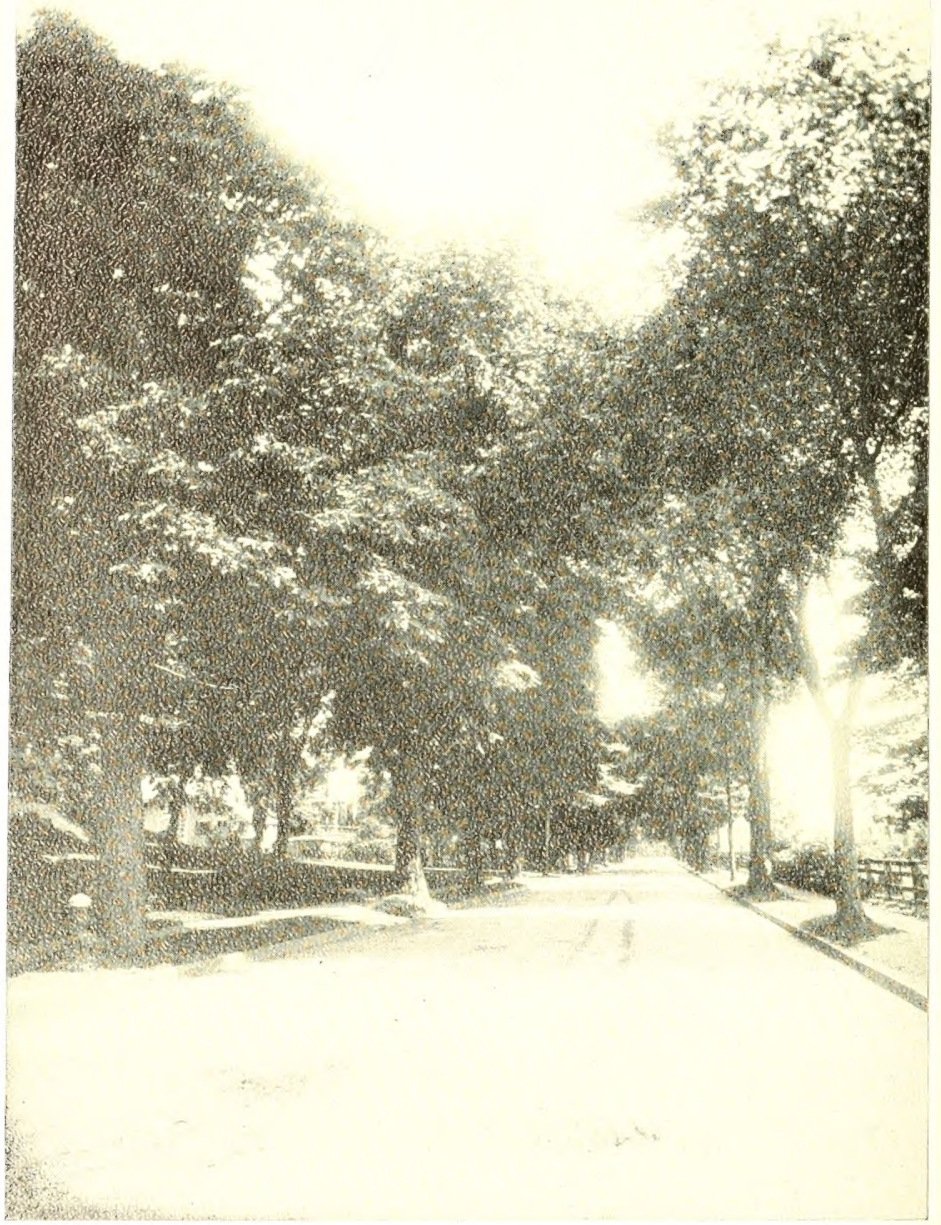

ELMS, NORTH FIFTH STREET 
"innocent and frequently recurring." To pass even one noble tree every day in going from the home to the workshop makes an appreciable addition to the satisfactions of the citizen.

The catalogue of the tree's utilities may bealtb easily be enlarged. Mr. W. A. Murrill, in Bulletin 205 issued by Cornell University, contends that "trees add to the healthfulness of a city by cooling and purifying the air. Besides cutting off the direct and reflected rays of the sun, foliage, by evaporating large quantities of water from its surface, exercises a marked effect on the temperature; and the reduction of the temperature in this way is greatest on dry, hot days when such reduction is most needed. Leaves also absorb impure and hurtful gases and manufacture the oxygen needed by us humans for respiration. Circulation of the air, due to unequal temperature, is likewise promoted by trees properly pruned and arranged; while the air of basements and cellars is rendered less humid by the removal of surplus water from the surrounding soil through the medium of roots and foliage.'

This appraisal of the tree as a sanitary factor is confirmed by the resolution of the New York County Nedical Society, quoted by C. Mulford Robinson in "The Improvement of Cities and Towns." The resolution follows:- "Resolved, That one of the most effective means for mitigating the Diminish Deatl. Rate intense heat of the Summer months and diminishing the death rate among children is the cultivation of an adequate number of trees in the streets." The sanitary value of the tree is illustrated further by the fact that the bill which was presented to the Legislature in 1899, to give the care of the street trees of New York City to the Park Commission, was drawn by a physician, a nember of the State Board of 


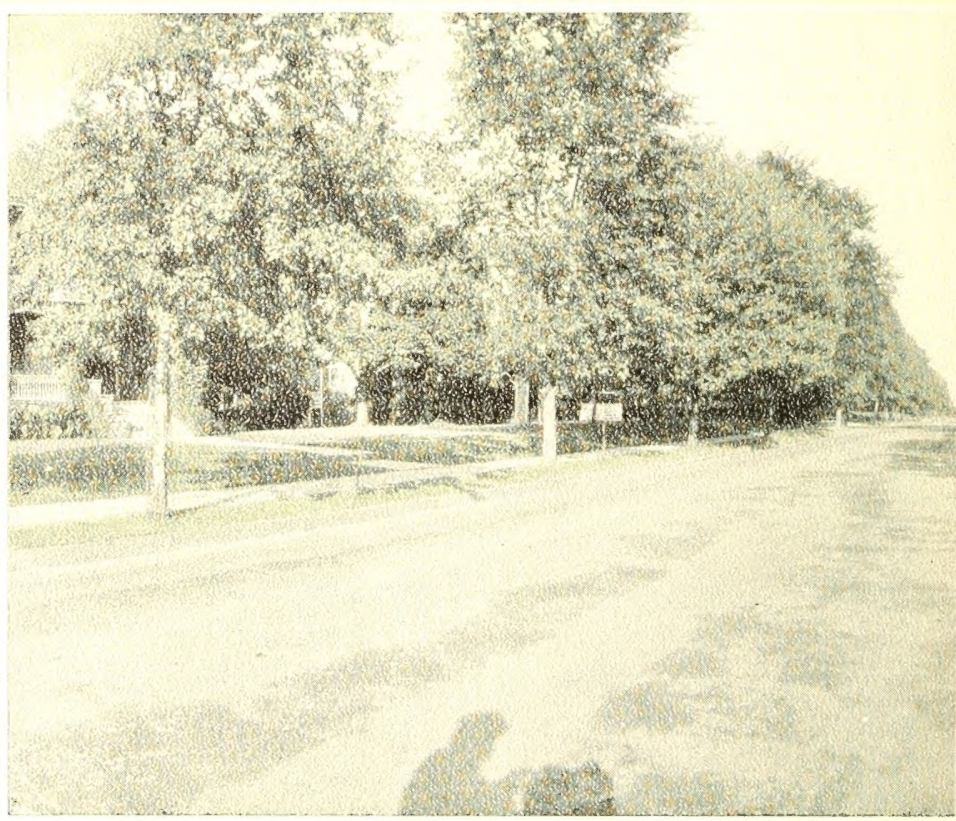

RED AND SUGAR M the Air

Health, and was introduced as a purely sanitary measure.

The air we breathe contains oxygen, carbonic acid gas. and ozone. The stipply of oxygen is demonstrably generated by the plant life of the globe. The carbonic acid gas. hurtful to anmal and helpful to vegetable life, is absorbed by the plants, and the proper atmospheric balance thus maintained. The large percentage of ozone in forest air, and the scarcity of it in the treeless streets where crow divellings abound, fenonstrates that this tonic and recuperative element of the air is due to the presence of trees and the lack of it to their absence. The air in the vicinity of 


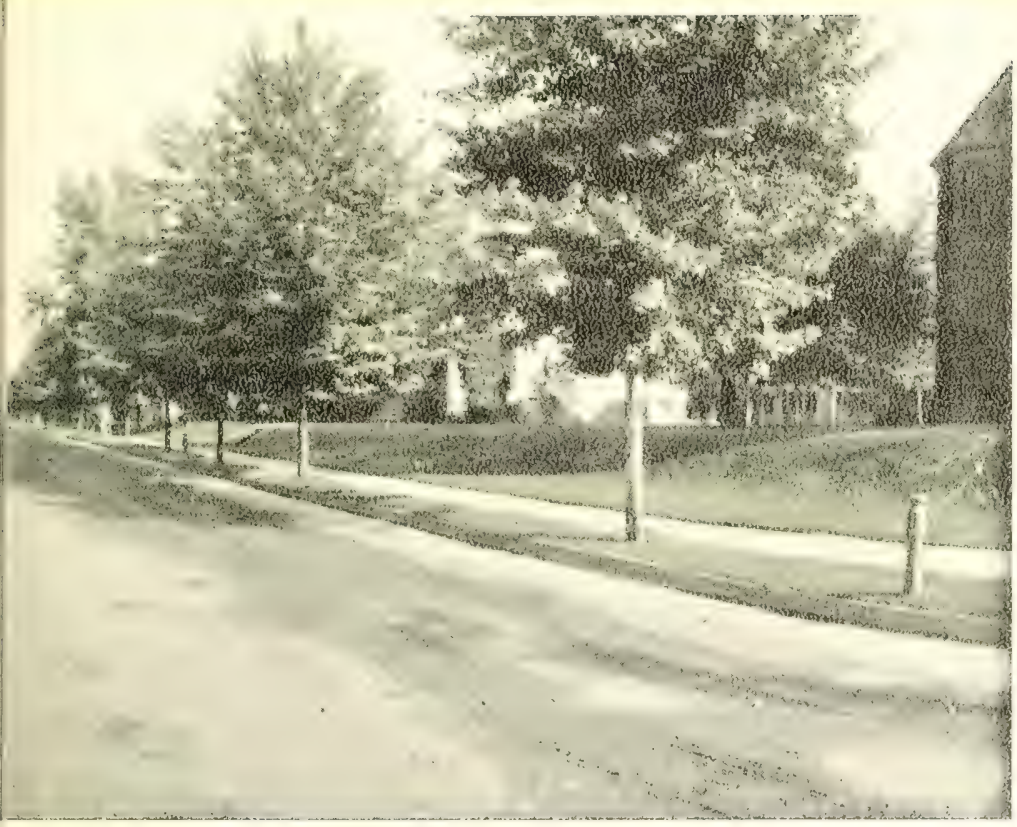

ES, MONTCLAIR AVENUE

trees contains less bacteria and (lust-particles than does the air ontsile of tree influence, which again demonstrates that the presence of trees decreases the total of atmospheric impurities. It is pertinent to note luere that a local varnish mannfacturer depends mpon his row of well-kept trees to screen much of the dust from the air before it enters his windows to injure his product.

sirects well planted with trees invite ont of cloor life by day and night, and the mut-doot life thus induced in no small degree thwarts the grim spectre of tuberculosis. now Trees and Lite so serions a menace to every individual in ont cities. 
Trees are among the first things which inKafalty presis a stranger in forming judgment as to Palturg whether a city is, or is not, a sood place to live in. ( )ne need not be a lover of nature to apTrees preciate the realty value of the refreshing shade of a row Appreciate I'ropesty of street trees when the sun is blazing. What relief, what rest to weary eyes is the verilure of trees after the glaring pavenents and shining winclows of a bare street-and how desirable then becomes a residence on the verdure covered street. 'These are evident truths, and that realty values appreciate in consefpence is equally apparent.

The contes reognize trees as an asset to the property on, or in fromt of which they stand. 'This real estate value of trees has been confirmed by numerons conte decisions. In many cases the conts have decided that the destruction of a street shate tree detracted from the value of the abutter's

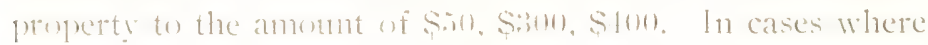
several trees fronting the same property have been destroged

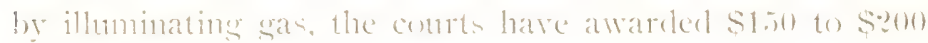
per tree to the abuter.

51, ind

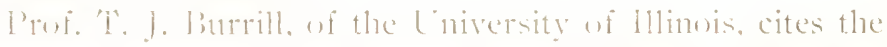
following instance of the money value of trees:- "lowo lots on the same street were offered for sale. Thlese lots were cesentialy sinnila in all respects sare that in one case there

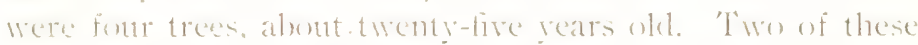
trees were in the street and two on the lot insicle of the street. In the case sif the other lot, the only treese t two of them, were on the street, and these were kess than half the age of the whers. 'The prices atsed for the lots were

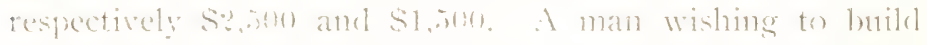

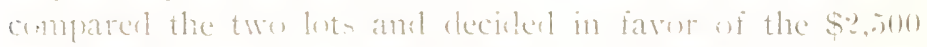
whe, the lot namely with the four trees-s1,0me for four arees, or we misht say for two trees. This lot had sixty-six 


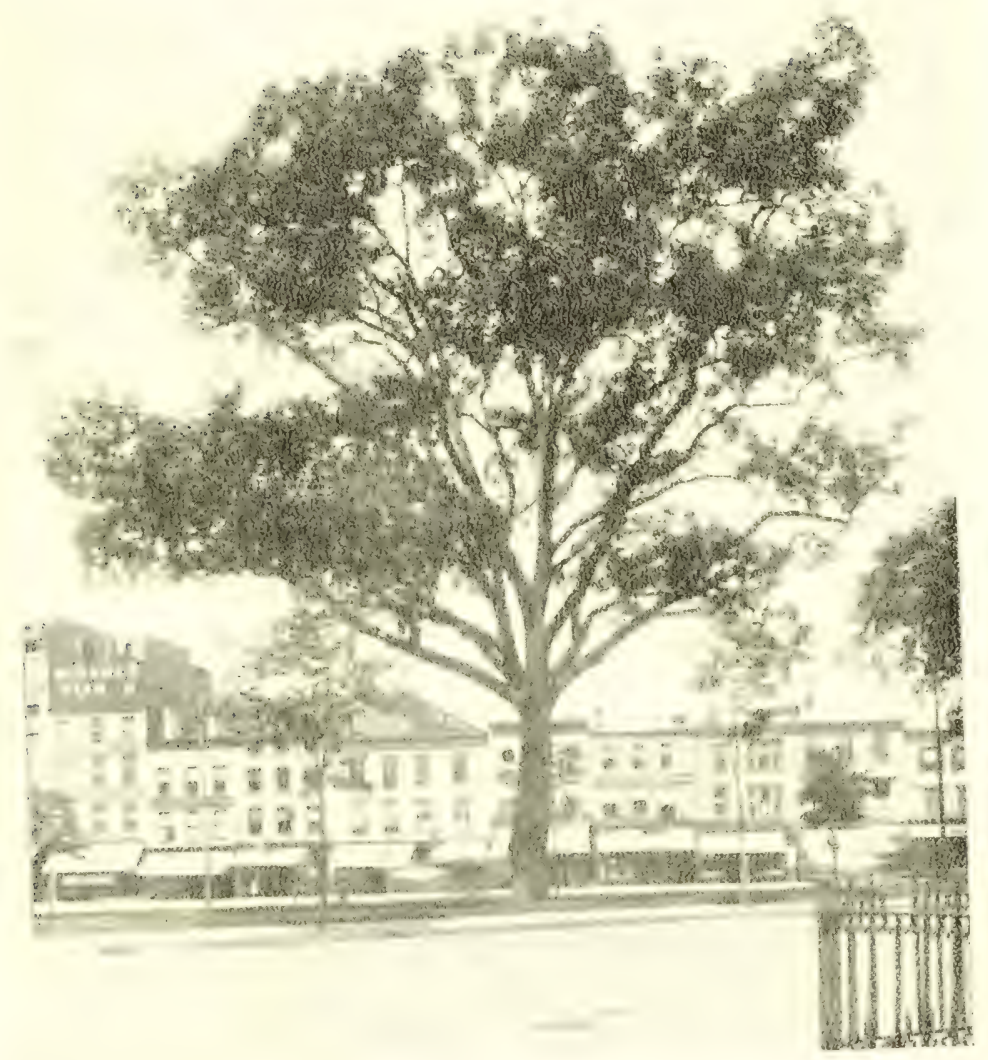

BLACK: WALNUT, BROAD STFEET

feet fromtage and contained abont one fonth of an acre. () 11 such an acreage the net profit for twenty-five annual

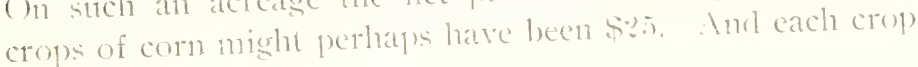




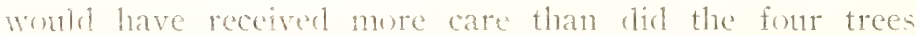

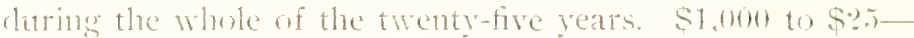
the contrast is instructive! Jet there are to-clay persons of intelligenee who, in looking formarl to results, will prefer to trust the corm.

It is a small task to plant a tree. The subseguent attention is not large. The trees once started help themselves as scarcely anything alse of moment to us ever cloes. 'They grout while we sleep. "loy drink the sunshine and comperund their omm lexel ont of the refuse gases of the air and the watery selution of the soil. Ont of these inert, inattractive, barde recomized substances, by a miracle of transformation there comen forth that thing of life and beantrwhich is also at thing of tangible nuoney value-a tree.

"Sientinent is three-fotnths of haman life,"

Batrotigm it has been said. I moment's retlection remothatrates the truth of the saying. Lowe of hemene, fore of friends, loxe of conntry, love of libertysentiments like these are the great motive forecs that move men to recels of high achievement. Ind not the least among these forces is the sentiment of patriotisin-the love of commtry. To what cffect this semtinent has wrought in the hearts of men, let Concond and lexington, I alley Forge and

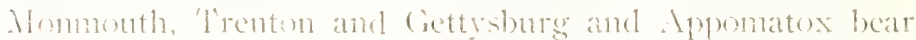
witness. Wo what it can achieve in termes of (lollars and cents, let the incalculable material wealth of this great nation, offspring of patriotism. sive testinony.

Now patriotism-love of comutry-is hut love of home whit have. Whatever fosters love of home fosters patrintisin. The home in and about which beatuty dwells-naterial beatuty. moral beatuty - is the bonte that wins and holds the heart. "l'hat, therefores which heantifies the lome-whether the home sterd, the home city, the home state or the hone 


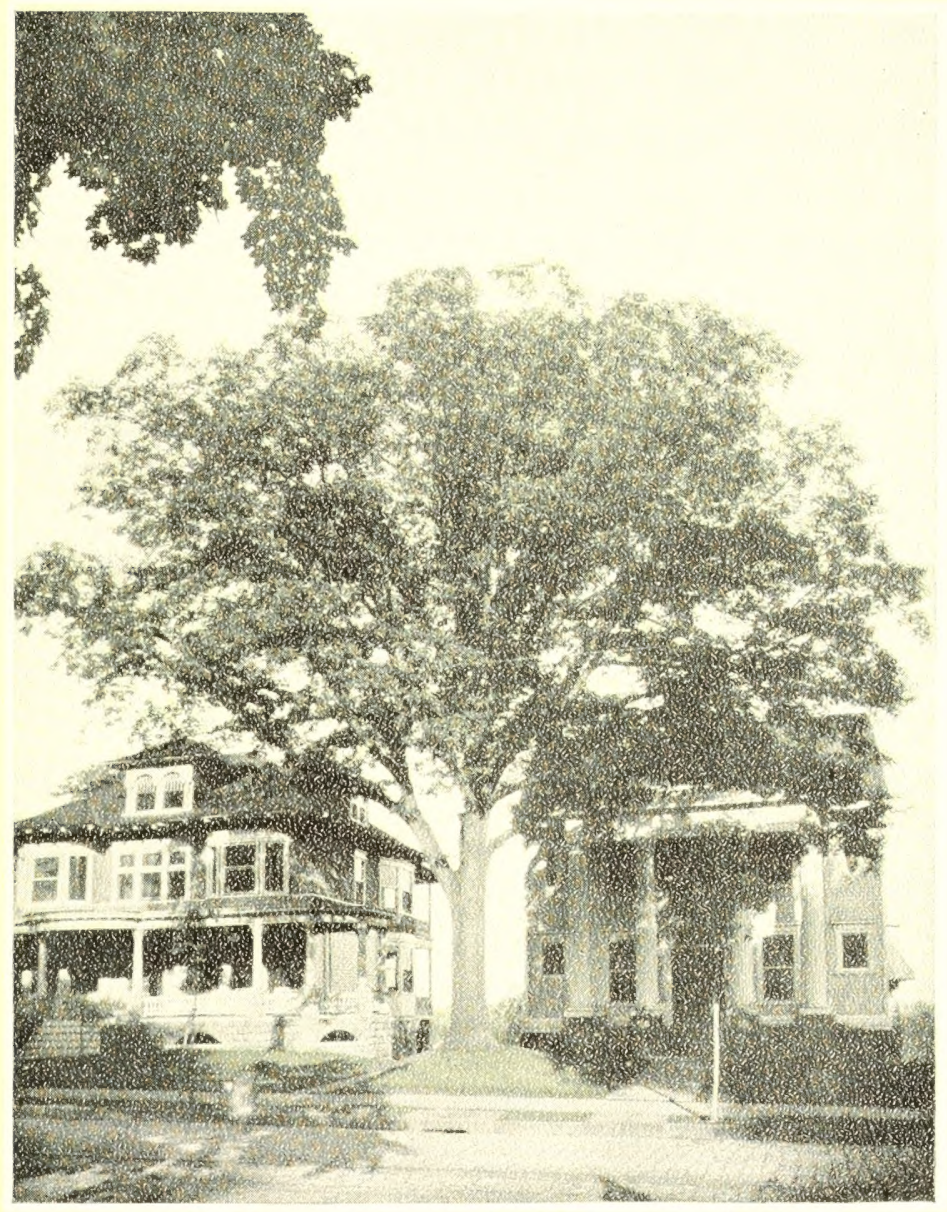

WHITE OAK, MT. PROSPECT AVENUE 
nation-becomes the nurse and hand-maiden of patriotism. Now trees beautify. The boy brought up in a country homestearl, overhtung by stately elms, approached through an avenue of maples or lindens, and having a dooryard hedged abont with lilacs, carries with him while he lives and whereer he wanders the picture of that beaty and the love of that bone. How the old homestead abides in the heart? How for love of it will not a man give all that he hath, even his life!

And as with the homestead, so with the home city. Trees beantify the city. That which beautifies the city of out

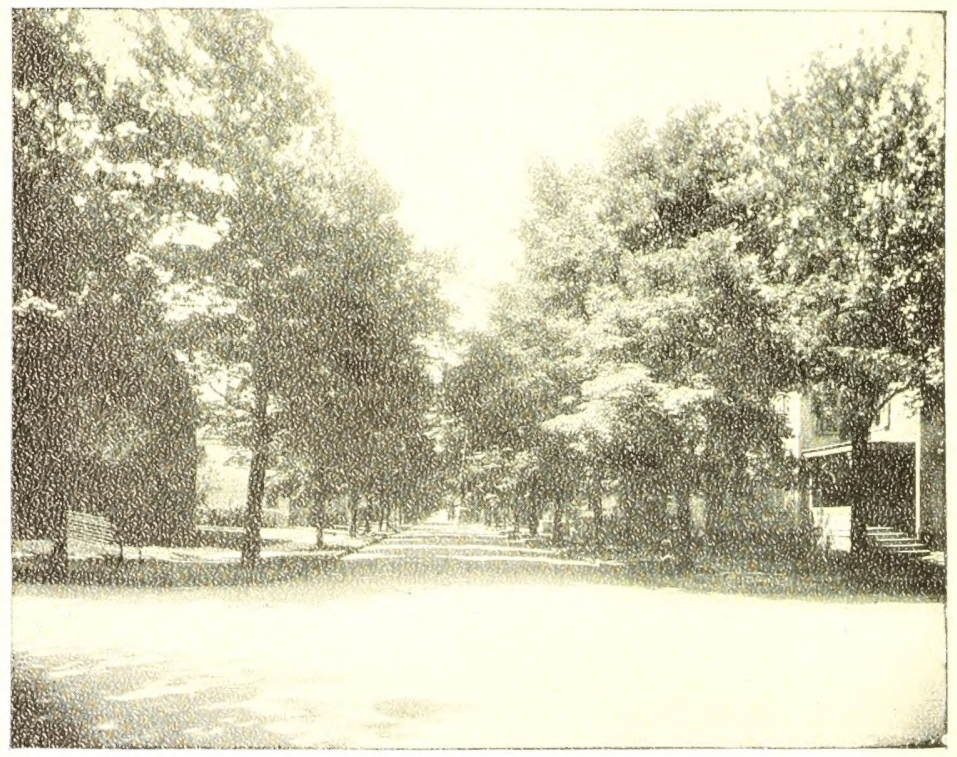

MAPIES, ELEVENTH ST. AND GOULD AVE. fooking South on Eleventh Street 
home endears that city to us, enlarges and deepens ont love for it - deepens and enlarges, that is to say, civic patriotism. The century old oaks and maples of Oxford, no less than its graceful towers and scholastic memories, gave the old City of Schools its grip on the love of Cecil Rhorles. The towering elms of New Haven and Cambridge hold for aye the hearts of the Men of Yale and of Harvard. The catalpas and maples of Princeton have had their part in inspiring the Sons of Nassau to cheer with such vigor, to battle with such might, to remember with such love, to ENDOW with such loyalty and liberality.

These feelings of pride in and tender affection for one's city, born of long association with and interest in the conmunity, and fostered by the beanty of the city's thoroughfares and buildings, are valuable assets. The wise city will seek to inculcate and conserve such sentiments. If from no other motive than municipal self-interest, civic patriotism should be cultivated. They who will do most for their city in even material things are they who love their city most. Our parks, our libraries, our schools, our churches our hospitals, our orphanages, our hoped for wharf fronts-in a word, all public benefactions will be brought in directly or indirectly by men who lo'e their city. As a mere material investment, then, if for no higher reason, make Newark beautiful with noble buildings and splendid parks and thoroughfares awave with trees. So shall the citizens love her the more. so shall they do exploits in her service.

In view of the foregoing, it is evident that an enlightened interest in the promotion of the beauty, the health, the realty values of our city, commends to civic patriotism the maintenance, protection and increase of the trees of Newark. 

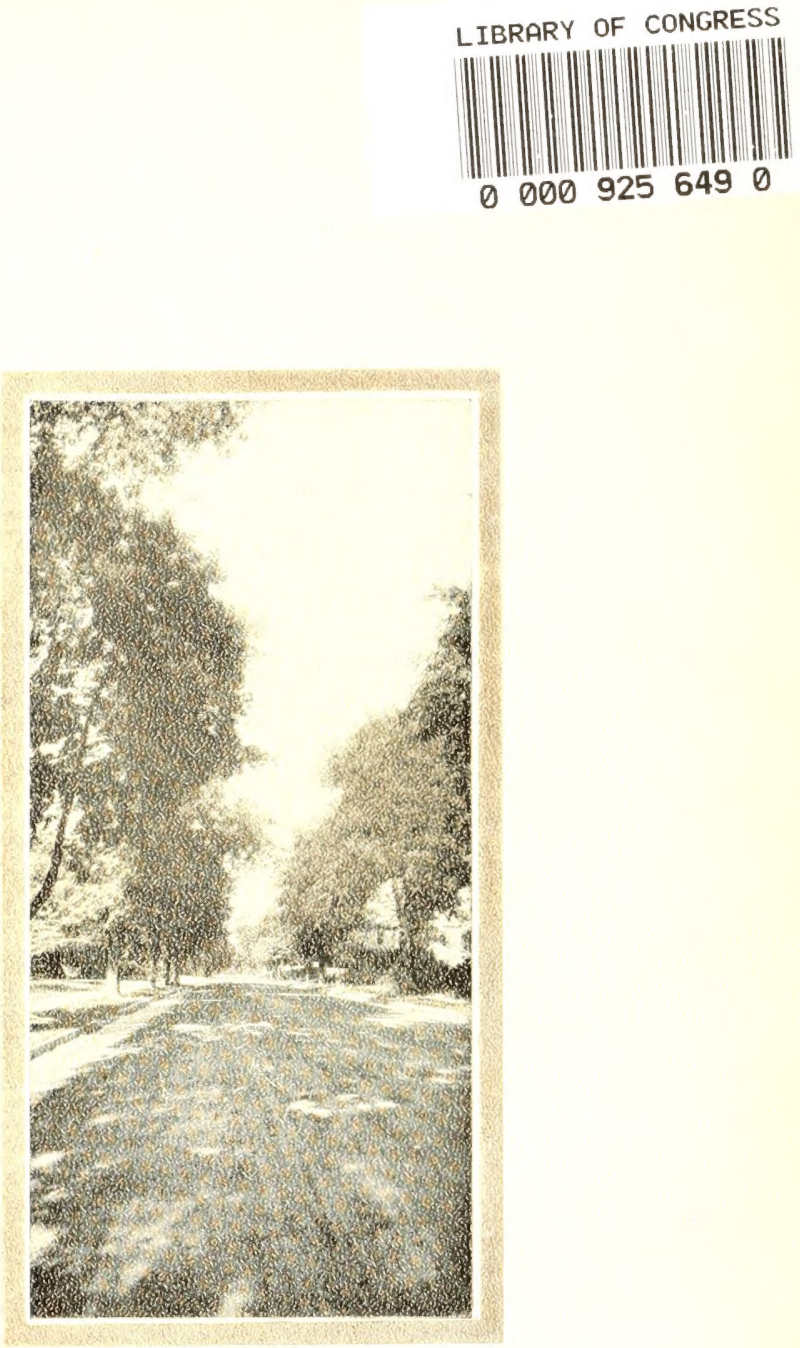

LINCOLN AVENUE 